\title{
Application of Geophysics for Quick Determination of Deposit in Mineral Exploration - A Case Study
}

\author{
Anthony Ewusi Jamel Seidu Sulemana Amadu \\ University of Mines and Technology, P O Box 237, Tarkwa, Ghana
}

\section{The research is self-financed}

\section{Abstract}

The Balatindi Mineral Prospect, Guinea, is a multi-element mineral prospect that hosts commercial quantities of gold, uranium and copper. A major challenge for exploration activities within the area is the turnaround time for assay results due to the unavailability of a nearby assay laboratory and the high cost of analysis. This therefore delays assay results which are needed for quick decisions during field work. There is therefore the need to find a faster and cheaper way of delineating mineral anomalies. Magnetic and radiometric geophysical techniques were considered because of the rapid and cost-effective ways in which data is acquired and they yield substantial quantity of accurate data enhancing interpretation and deduction. Down hole drill data for 37 HQ size diamond drilled holes of about $9200 \mathrm{~m}$ were used for the analysis. Magnetic susceptibility data were secured from 24 drill hole data for the Central Polymetallic Prospect area, whiles radiometric data were taken for the 23 drill holes in the other areas. The data were correlated with the laboratory assay results for gold and uranium respectively. Strip logs and statistical analysis were used to interpret magnetic susceptibility readings against gold assay values, and radiometric readings against uranium assay values. Maximum and minimum values of $-2.46 \times 10^{-3}$ and $546.5 \times 10^{-}$ ${ }^{3}$ magnetic susceptibility were respectively recorded whiles $45 \mathrm{cps}$ and $7250 \mathrm{cps}$ were the maximum and minimum radiometric readings obtained. Magnetic susceptibility values did not show any preferential correlation with gold mineralisation. Radiometric cps values showed a very strong direct correlation with uranium mineralisation. This is because the radiometric cps is a function of the radiometric mineral present and therefore, radiometric survey can be used as a faster and cost-effective way of delineating uranium anomaly within the Balatindi prospect.

Keywords: Balatindi, Magnetic susceptibility, Radiometric count, Multi-element mineral deposit.

DOI: $10.7176 / \mathrm{JNSR} / 11-18-04$

Publication date:September $30^{\text {th }} 2020$

\section{Introduction}

The Balatindi Mineral Prospect (BMP) is a highly prospective multi-element mineral deposit of Iron Oxide, Copper, Gold and Uranium (IOCGU) type located in the eastern part of the Republic of Guinea. It potentially hosts commercial quantities of Gold, Uranium and Copper. Two mineralised domains are observed at Balatindi; golddominated mineralisation in the Central Polymetallic Prospect (CPP) hosted within a granodiorite sheet sandwiched between two layers of Archaean quartz-amphibole gneiss, immediately north of an interpreted eastwest trending thrust (Egal et al., 2002) and uranium dominated mineralisation developed south of the thrust. The location of the prospect presents a practical problem in terms of turnaround time for assay results. The closest analytical laboratory is located in Bamako, Mali, where it takes a minimum of three months to receive assay results. Also the high cost of assay analysis presents a huge challenge in program planning and execution. A quicker and cheaper way of delineating anomalous zones is required for quick decision making in the field.

Magnetic susceptibility detects subtle changes in composition that can be linked to paleoclimate-controlled depositional processes and mineralisation. The high precision with which these measurements are taken makes it extremely useful for core-to-core and core-downhole log correlation (Tarling and Hrouda, 1993). Tsiboah and Arko (1999) carried out magnetic susceptibility measurements on fresh rocks of the Birimian volcanic greenstones of the Ashanti Belt and observed a genetic relationship between magnetic susceptibility and gold mineralisation within the Birimian rocks of Ghana. Also, Wemegah et al. (2009) carried out magnetic susceptibility characterisation on mineralised and non-mineralised rocks from the Subensu concession of Newmont Ghana Gold Limited and detected a general decrease in the magnitude of magnetic susceptibility of rocks with increase in rock alteration and corresponding increase in gold assay values. In the Hishikari epithermal gold deposit of Japan, Murakami, (2007) successfully used magnetic susceptibility to identify hydrothermally altered zones, including alteration halos close to quartz veins. Similarly, radiometric survey is a very useful tool in delineating radiometric anomalies, particularly uranium, and lithological contacts (Gabor and Peter, 2011). In the North Shore property, Canada, Lafleur, (2006) successfully delineated drill targets for uranium using radiometric survey data. Also, drill targets were delineated on properties located in the Sudbury Mining District of Northern Ontario, Canada, using detailed ground radiometric survey (Anon, 2009). In the exploration for uranium at Wadi Um Laseifa area, Egypt, Ramadan et al (2002) used the SPP 2 NF scintillometer to select high anomalous areas for rock sampling and this approach was successful in delineating the uranium anomaly. This paper seeks to establish a relationship between magnetic susceptibility and radiometric surveys with gold and uranium mineralisation on the Balatindi deposit and 
use the relationship to delineate anomalous zones faster and cheaper during exploration.

\section{Materials and Methods \\ 2.1 Location and Accessibility}

The BMP area covers an E-W elongate rectangular area of about $249 \mathrm{~km}^{2}$, which traverses a portion of the common boundary between Kerouane and Damaro-Odienne, and lie partly in each of the two administrative prefectures, Kankan and Kerouane. It is located $80 \mathrm{~km}$ south of Kankan, Guinea's second largest city, after Conakry. The Balatindi area falls within the Guinea interior highlands which has undulating topography with elevations ranging between $300 \mathrm{~m}$ and $700 \mathrm{~m}$ above sea level. It is drained by several easterly trending streams that are tributaries of the Dion River. The highest peak, the Balatindi Hill, dominates the middle part of the property. The climate within the area is tropical with relatively high humidity throughout the year. Precipitation is generally high, about 1,200 mm annually.

\subsection{Geology}

The BMP is located in eastern Guinea within the Bale Mylonitic Zone. This Zone forms part of a broad tectonomagmatic belt developed between the Archaean Kénéma-Man Craton to the south and the Paleoproterozoic Birimian Siguiri basin to the north. The belt rims the margin of the craton in eastern Guinea. In the region around Balatindi, the belt is $50-100 \mathrm{~km}$ wide and trends east-west to WNW-ESE for approximately $150 \mathrm{~km}$. The belt is late Eburnean in age and comprises a variety of pre- to syn-tectonic granitic rocks (granodiorite, biotite granite, monzogranite and two-mica granite) with an anastomosing network of major WNW-ESE trending ductile sinistral strike-slip fault zones characterised by intense mylonitic to ultramylonitic deformation. This tectono-magmatic belt is considered to have undergone deformation during regional shortening towards the WSW, which was mainly accommodated by sinistral strike-slip movement (Robertson and Witley, 2013). The setting of Balatindi within a tectono-magmatic belt adjacent to an interpreted active margin and overlying a subduction zone represents a classic setting for porphyry deposits, although porphyry deposits in Paleoproterozoic-age rocks are uncommon. However, Mesozoic Andean-type Iron Oxide, Copper and Gold (IOCG) deposits occur in a similar tectonic setting (Robertson and Witley, 2013). Although the element association of the two mineral systems is similar to the typical geochemical association observed in IOCG deposits, iron contents are low, with a typical range (based on the Burey multi-element data) of $2-4 \% \mathrm{Fe}$, with an average of $2.85 \% \mathrm{Fe}$. Further, there appears to be little evidence for hydrothermal brecciation in the Balatindi system.

Egal, et al., (2002) considered the chemistry of the granitic rocks within this belt to be similar to magmatic suites developed on active margins above subduction zones. Evidence of strong contamination from the Archaean Kénéma-Man Craton supports emplacement of the plutonic belt directly above a subduction zone. This is the classic setting for the generation of porphyry type mineral deposits. Local mapping within Balatindi found gneiss, granodiorite, monzogranite and andesite as the major rock types outcropping in the property. Diamond drilling however, reveal a wide variety of rock units that do not outcrop on surface. In the CPP, a granodiorite sheet is sandwiched between two layers of Archaean quartz-amphibole gneiss immediately north of an interpreted E-W trending thrust. This area hosts the Gold mineralisation. Uranium-dominated mineralisation is developed south of the thrust (Robertson and Witley, 2013) as shown in Figure 1. 


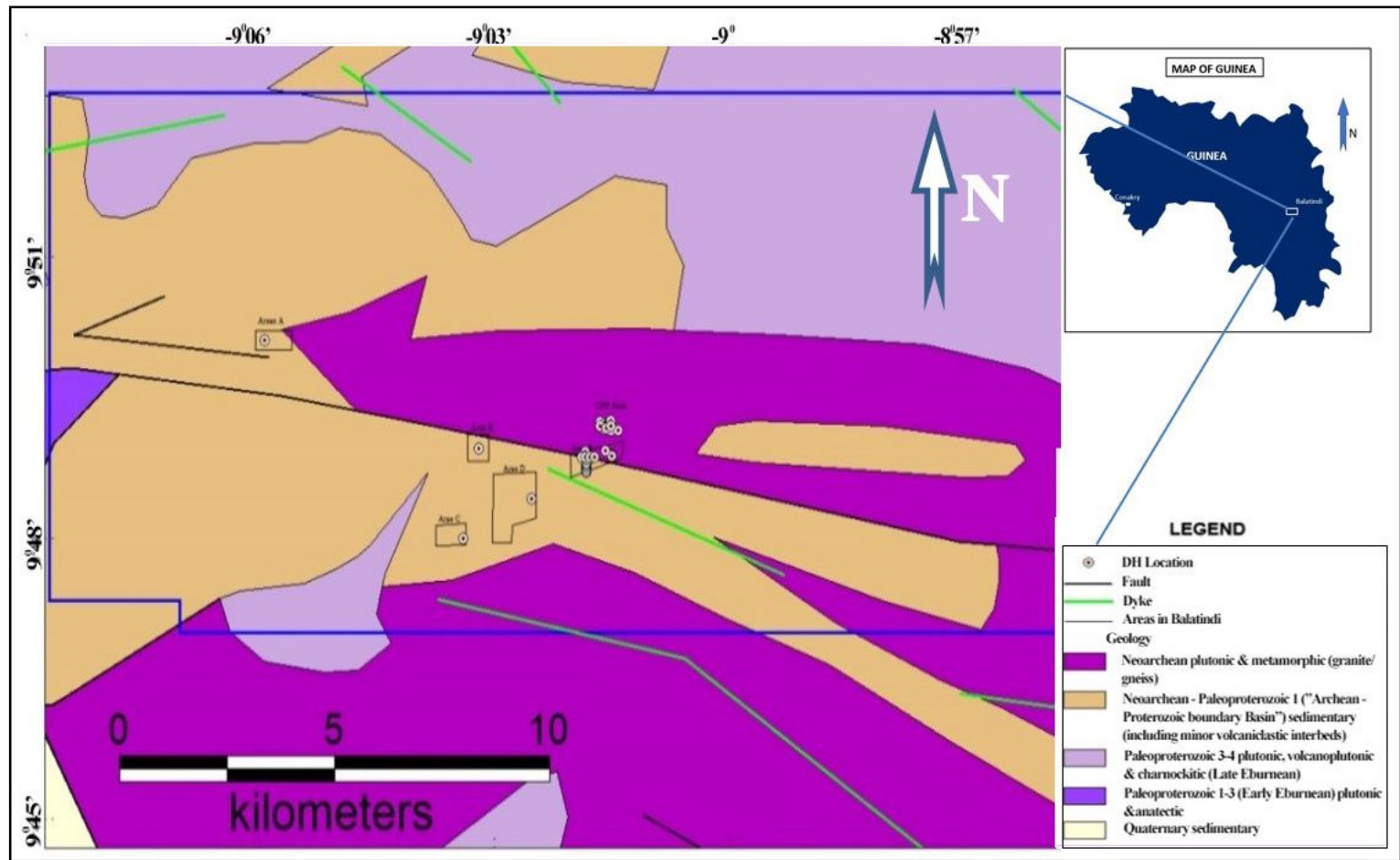

Figure 1. Geological Map of the Balatindi Area

Mining Italiana viewed mineralisation in terms of a porphyry model, with a yet to be discovered porphyry body and mineralisation associated with hydrothermal fluids. The Balatindi system appears to be a hybrid between an IOCG and porphyry model; however essentially the same exploration approach would be required in terms of delineating these types of deposits. Uranium-copper mineralisation occurs in sub parallel zones which dip to the south at approximately $45^{\circ}$. The mineralisation follows an E-W trend aligned with the radiometric anomaly and a sinistral displacement along a northeast trending fault.

\subsection{Geophysical methods}

\subsubsection{Magnetic Susceptibility}

Materials can be classed into three groups according to their magnetic structure. These are; diamagnetic materials whose magnetic susceptibility is negative, paramagnetic materials have positive susceptibility, but generally low and ferromagnetic materials which have high magnetic susceptibility (Tarling and Hrouda, 1993). Ferromagnetic materials are the most important in paleomagnetism in that they carry remnant magnetism. Lindsley et al., (1966) assert that magnetic susceptibility is generally related to the magnetite content of rocks. However according to Hrouda et al., (2009), magnetic susceptibility of rocks is in principle controlled by the type and amount of magnetic minerals contained in a rock. Sometimes, it is dominantly controlled by paramagnetic minerals (mafic silicates such as olivine, pyroxenes, amphiboles, micas, tourmaline, garnets), often by ferromagnetic minerals (iron oxides or sulphides, represented for instance by magnetite and/or pyrrhotite, respectively) and much less frequently by diamagnetic minerals (calcite, quartz). As the ferromagnetic minerals mostly belong to accessory minerals that are often sensitive indicators of geological processes, the magnetic susceptibility is a useful parameter in solving some petrologic problems (Hrouda et al., 2009). Except for rare monomineralic rocks, rocks consist in general of all three kinds - i.e. diamagnetic, paramagnetic and ferromagnetic minerals. In strongly magnetic rocks, the magnetic susceptibility is controlled mostly by the presence of ferromagnetic minerals (Figure 2a). In rocks with the lower magnetic susceptibility, the susceptibility may be controlled by both paramagnetic and ferromagnetic minerals, according to the rock mineral composition. In some monomineralic rocks, such as limestone, marble, quartzite, if the content of ferromagnetic and paramagnetic minerals is very low or zero, the susceptibility can be negative, being controlled by the presence of diamagnetic calcite or quartz. In general, the susceptibility depends on the ratio of $\mathrm{Mg}$ to $\mathrm{Fe}$ components (Figure 2b). Similar situation exists in olivine, garnets and amphiboles. In titanomagnetites, the susceptibility depends on the amount of the titanium in the mineral (generally, it decreases with increasing Ti content (Figure 2c). 


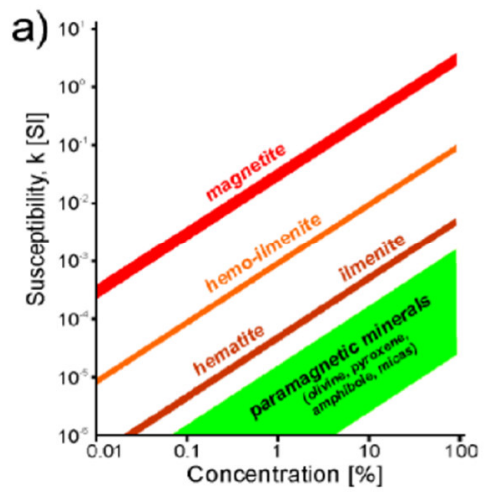

b)

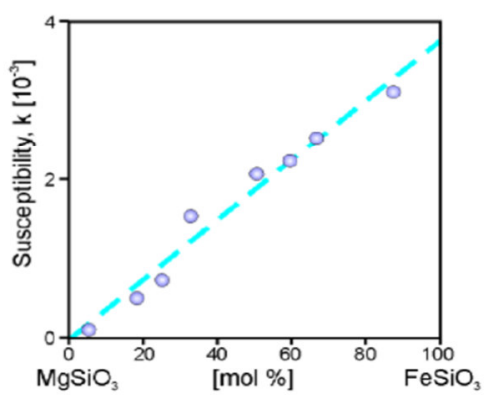

c)

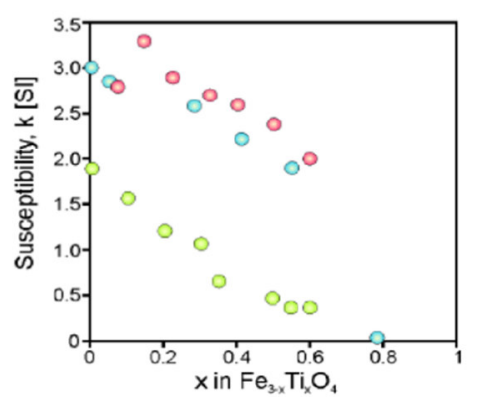

Figure $2(\mathrm{a}, \mathrm{b}, \mathrm{c})$. Contribution of individual rock forming minerals to total magnetic susceptibility of the rock

(Hrouda et al., 2009)

Magnetic susceptibility is easily measured and can execute numerous detailed measurements in a reasonable time. Even though the mafic rocks show in general higher susceptibility than felsic rocks, there are many examples of light granites being both weakly and strongly magnetic. On the other hand, some dark rocks as gabbro and lamprophyres can be weakly magnetic. In addition, Fe ores with magnetite have high susceptibility, while the Fe ores with dominating hemoilmenite and having the same Fe content can show much lower susceptibility. Also, magnetic susceptibility depends on geochemical or mineralogical composition of the rocks and on later metamorphic processes and alterations. Very important controlling factors are also fugacities of $\mathrm{O}_{2}$ and $\mathrm{S}$. Magnetic susceptibility provides us with invaluable information in this respect (Evans and Heller, 2003).

\subsubsection{Radiometric Survey}

Radiometric surveys are applicable in several fields of geoscience. They retain their geological and geophysical information for mineral prospecting, geochemical mapping and structural geology, and enable the comparison of geological features over large regions. Gamma ray spectrometry as a tool for mapping radioelement concentrations has found widespread acceptance in diverse fields. The method has benefited from continuing advances in instrumentation, field procedures, and calibration and data processing procedures. Gamma ray spectrometry has been widely used for environmental mapping, geological mapping and mineral exploration (Aboelkhair and Zaaeimah, 2013; Wilford et al. 1997; Tourlière et al. 2003). Radioactive decay also often occurs in a series (or chain) with a number of daughter products, which are also radioactive, and terminates in a stable isotope. In a closed system and starting with a specified amount of a mother element, the number of atoms of daughter elements and their activity grows gradually until radioactive equilibrium of the disintegration series is reached. The measurement of the concentration of any daughter element can be used to estimate the concentration of any other element in the decay series. Though many naturally occurring elements have radioactive isotopes, only potassium, and the uranium and thorium decay series, have radioisotopes that produce gamma rays of sufficient energy and intensity to be measured by gamma ray spectrometry. This is because they are relatively abundant in the natural environment. Average crustal abundances of these elements are in the range 2-2.5\% K, 2-3 ppm U and 8-12 ppm Th. Gamma radiation is used in geophysical radiometry due to its larger penetration depth, compared with alpha and beta radiations (Gabor and Peter, 2011). The source of gamma radiation can be natural or artificial. The natural gamma radiation that is measured, emanates from many rock types, those containing uranium and potassium being most active including granites, shales and clays, and from radon gas in the atmosphere as a by-product of uranium.

\subsection{Methods Used}

Magnetic susceptibility, radiometric, lithological and multi-element assay data for core samples from thirty-seven (37) HQ size diamond drilled holes of about $9200 \mathrm{~m}$ were used. The SM30 magnetic susceptibility meter and SPP2 NF Scintillometer were used for magnetic susceptibility and radiometric measurements respectively. The magnetic susceptibility readings were taken at $20 \mathrm{~cm}(0.2 \mathrm{~m})$ intervals. Drill core radiometric readings were taken using the Saphymo-SRAT SPP2 NF Scintillometer. The operation range for gamma radiation is 0.02 to 30 microsieverts per hour $(\mu \mathrm{Sv} / \mathrm{h})$. The instrument has an in-built audible alarm that gives a high signal. The threshold and the frequency of the sound alarm can be varied according to the strength of radiation. The time constant for the sound alarm is 0.25 seconds.

\subsubsection{Laboratory Assay}

After obtaining lithological, structural, radiometric and magnetic susceptibility information, the drill core was marked for sampling taking into consideration lithological and structural boundaries. The core was split into equal halves. One half was processed for submission to the laboratory for assay analysis and the other half stored for reference. Samples were sent to the laboratory, for analysis. Samples from the CPP area were analysed for gold whilst multi-element analysis was carried out for samples from the other areas. 


\subsubsection{Data Processing}

The magnetic susceptibility data was taken at $2 \mathrm{~cm}$ interval, the radiometric readings were taken at $1 \mathrm{~cm}$ interval whilst laboratory assay samples were taken at least $50 \mathrm{~cm}$ and at most $200 \mathrm{~cm}$ depending on the geology and structure of the interval. In order to carry out the comparative analysis required in this project, the gold assay values were composited at $2 \mathrm{~cm}$ interval whilst assay values for uranium were composited at $1 \mathrm{~cm}$ interval. Compositing allows effective use of observational and statistical methods to do comparative analysis. Sample interval that had no magnetic susceptibility or radiometric readings taken were not included in the analysis.

\section{Results and Discussions}

Magnetic susceptibility data were taken for the 14 drill holes located within the CPP area, whiles radiometric data were taken for the 23 drill holes in the other areas. The data was correlated with the laboratory assay results for gold and uranium respectively. Strip logs and statistical analyses were used to interpret magnetic susceptibility readings against gold assay values, and radiometric readings against uranium assay values.

\subsection{Magnetic Susceptibility}

The SM 30 magnetic susceptibility meter which reads in $10^{-3}$ units was used. The minimum and maximum susceptibility values recorded were $-2.46 \times 10^{-3}$ and $546.5 \times 10^{-3}$ respectively. The various mineralised and nonmineralised rock units gave varied magnetic susceptibility values.

\subsubsection{Quartz Monzonite}

These units occur as quartz-phyric dykes in the granitoids and other geological units. They are generally less mineralised with sizes ranging between veinlets to $15 \mathrm{~m}$ wide. These dykes exhibit a low magnetic susceptibility, even though elevated values were recorded at intervals where the unit host relics of granodiorite. The low magnetic susceptibility value is attributed to the presence of quartz which is the most dominant mineral in the unit. Quartz is diamagnetic and generally has a low magnetic susceptibility. Typical of this observation made on BLDD003 as illustrated in Figure 3. Values between $0.007 \times 10^{-3}$ and $59.7 \times 10^{-3}$ were recorded. An average of $7.7 \times 10^{-3}$ magnetic susceptibility is high in absolute terms, but it is relatively low in comparison to the average magnetic susceptibility in the Balatindi area. A scatter plot of magnetic susceptibility readings against gold assay values for quartz monzonite is given in Figure 4.

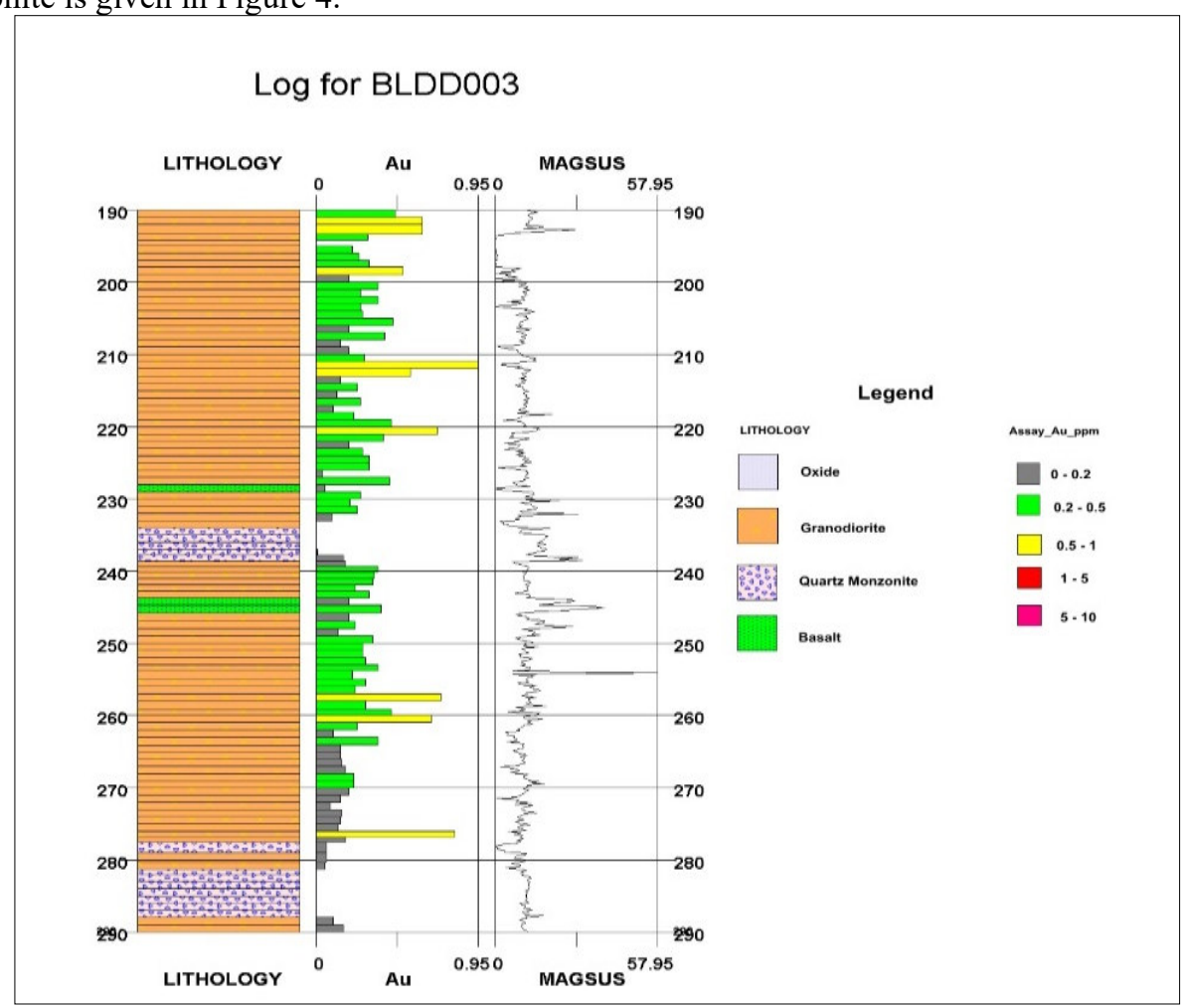

Figure 3. Quartz Monzonite Showing Low Magnetic Susceptibility in BLDD003 


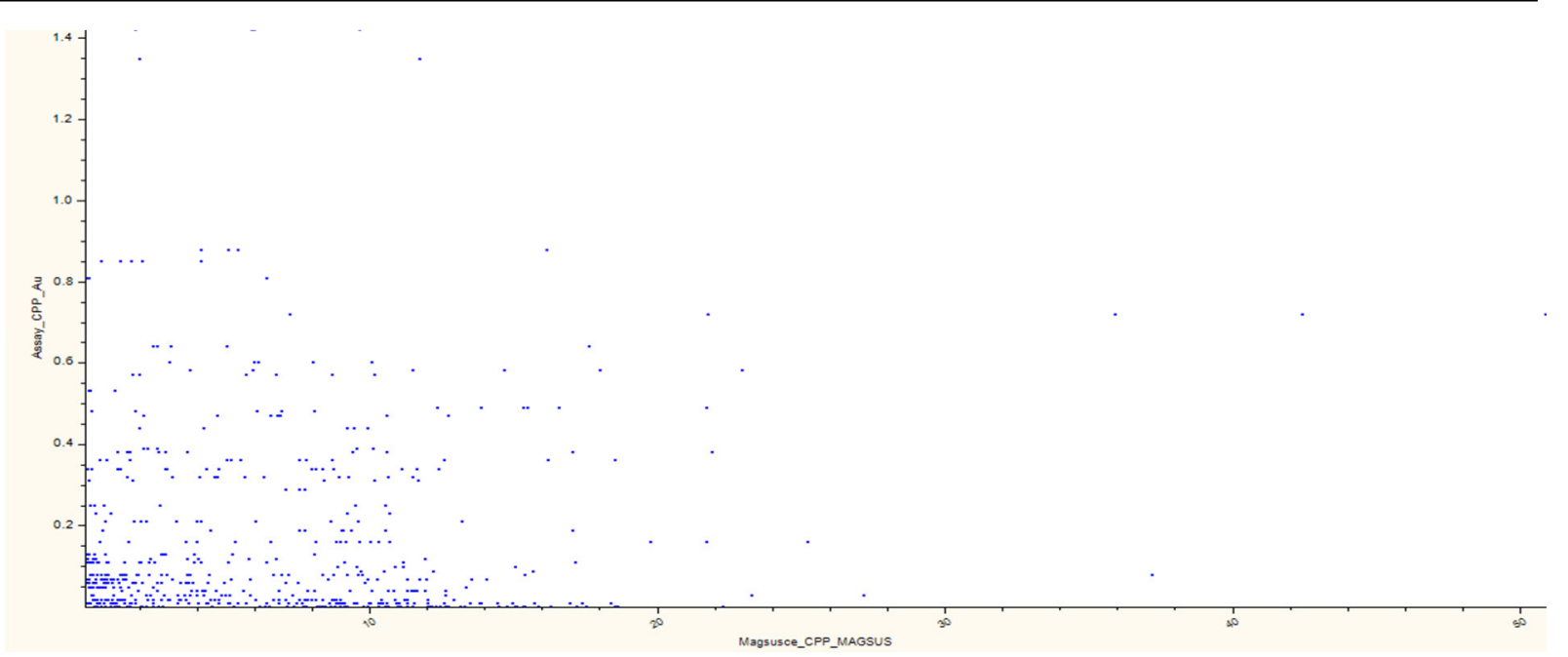

Figure 4. Scatter Plot of Magnetic Susceptibility against Au Assay Values for Quartz Monzonite

\subsubsection{Greywacke}

Greywacke encountered downhole also exhibit relatively moderate magnetic susceptibility. It constitutes massive units. $0.33 \times 10^{-3}$ and $54.25 \times 10^{-3}$ are the maximum and minimum susceptibility recorded for the unit. The unit was intercepted only at the bottom of BLDD006. Gold mineralisation is also restricted to zones with quartz veins and inclusions of granodiorite. Figure 5 shows the bottom part of BLDD006, while Figure 6 shows the scatter plot of magnetic susceptibility readings against gold assay values.

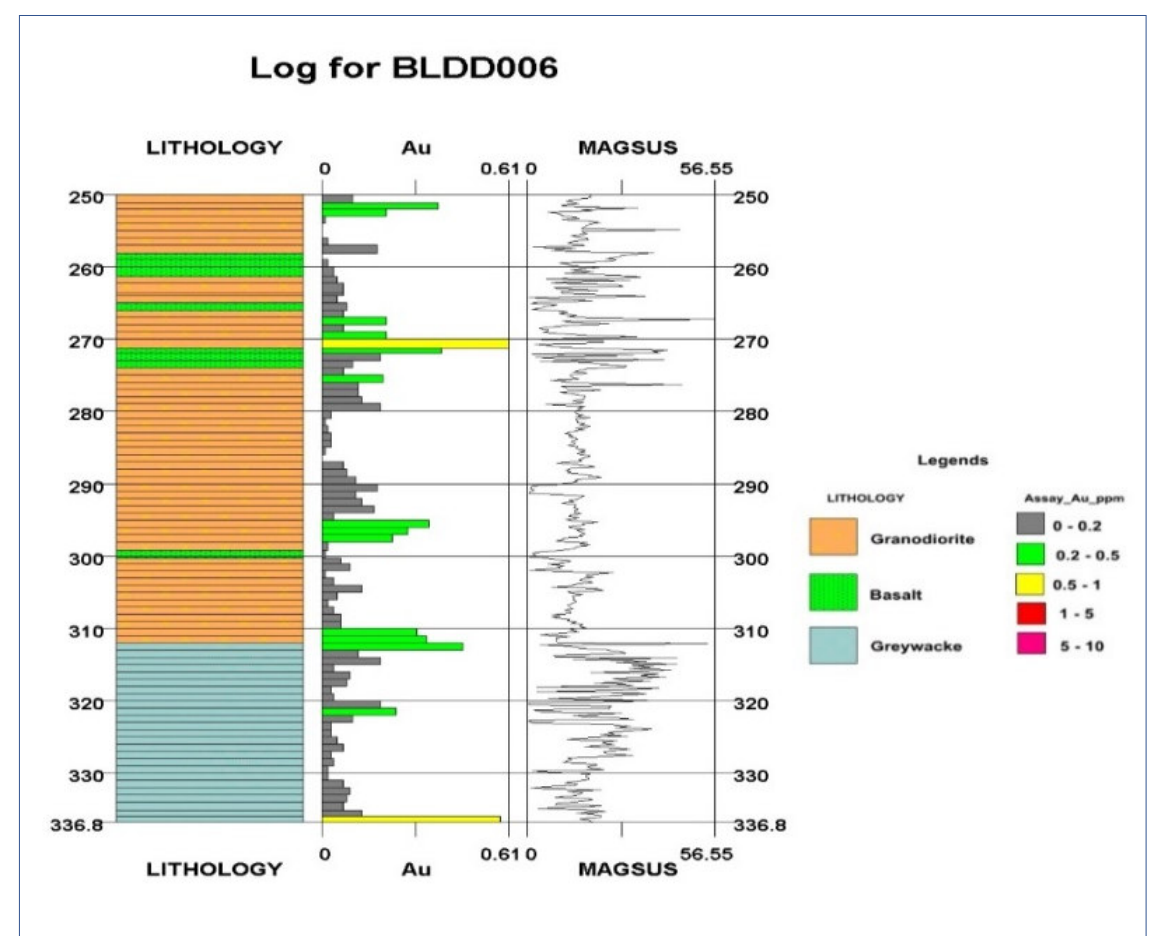

Figure 5. BLDD006 Showing Au and Magnetic Susceptibility Values in Relation to Greywacke 


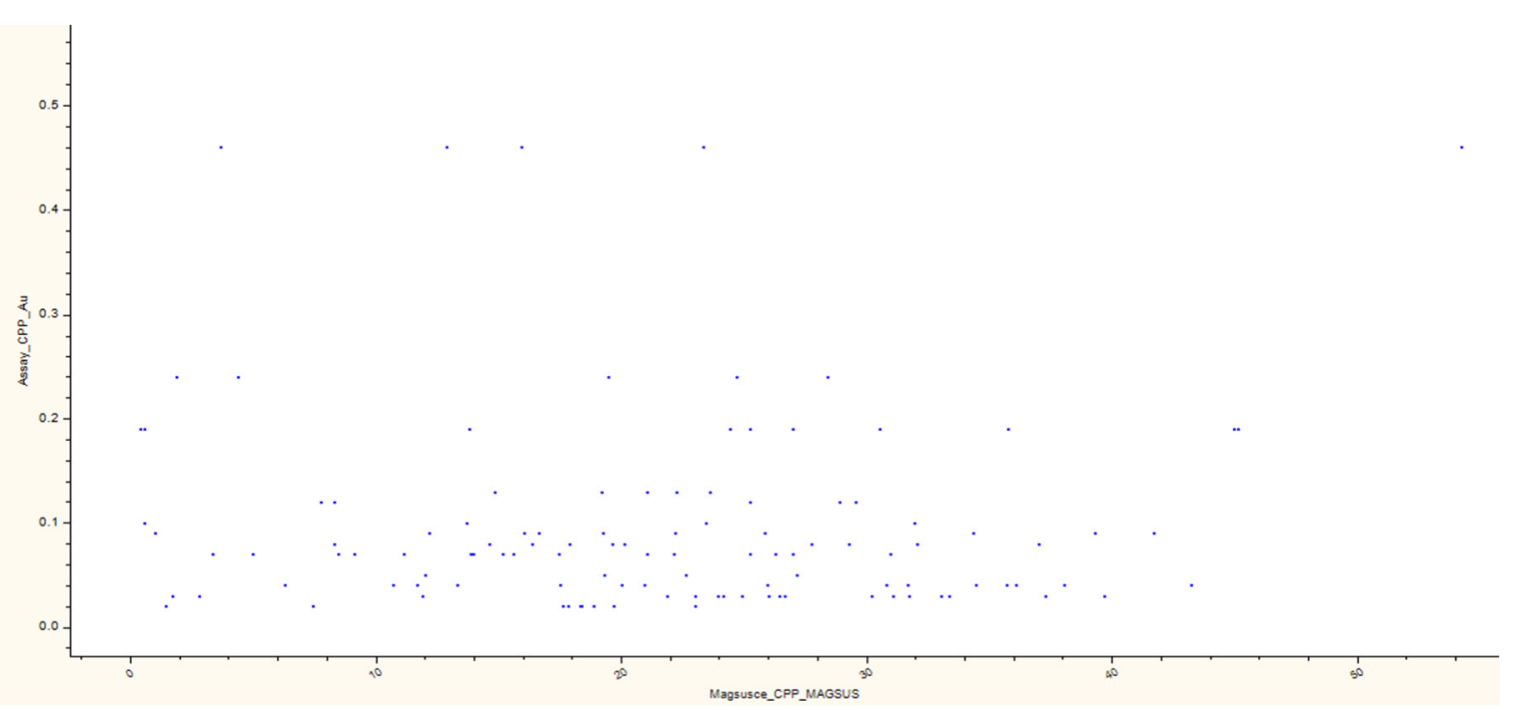

Figure 6. Scatter Plot of Magnetic Susceptibility against Au Assay Values for Greywacke

\subsubsection{Basalt}

Maximum and minimum susceptibility values of $166.45 \times 10^{-3}$ and $0.04 \times 10^{-3}$ were recorded for basaltic units. The average value of $18.3 \times 10^{-3}$ is the highest for a rock unit in the CPP area. Gold values are generally low and unrelated to the magnetic susceptibility values. Figure 7 shows areas of high magnetic susceptibility giving low $\mathrm{Au}$ anomalies in BLDD035 and Figure 8 shows the scatter plot of magnetic susceptibility and gold assay values.

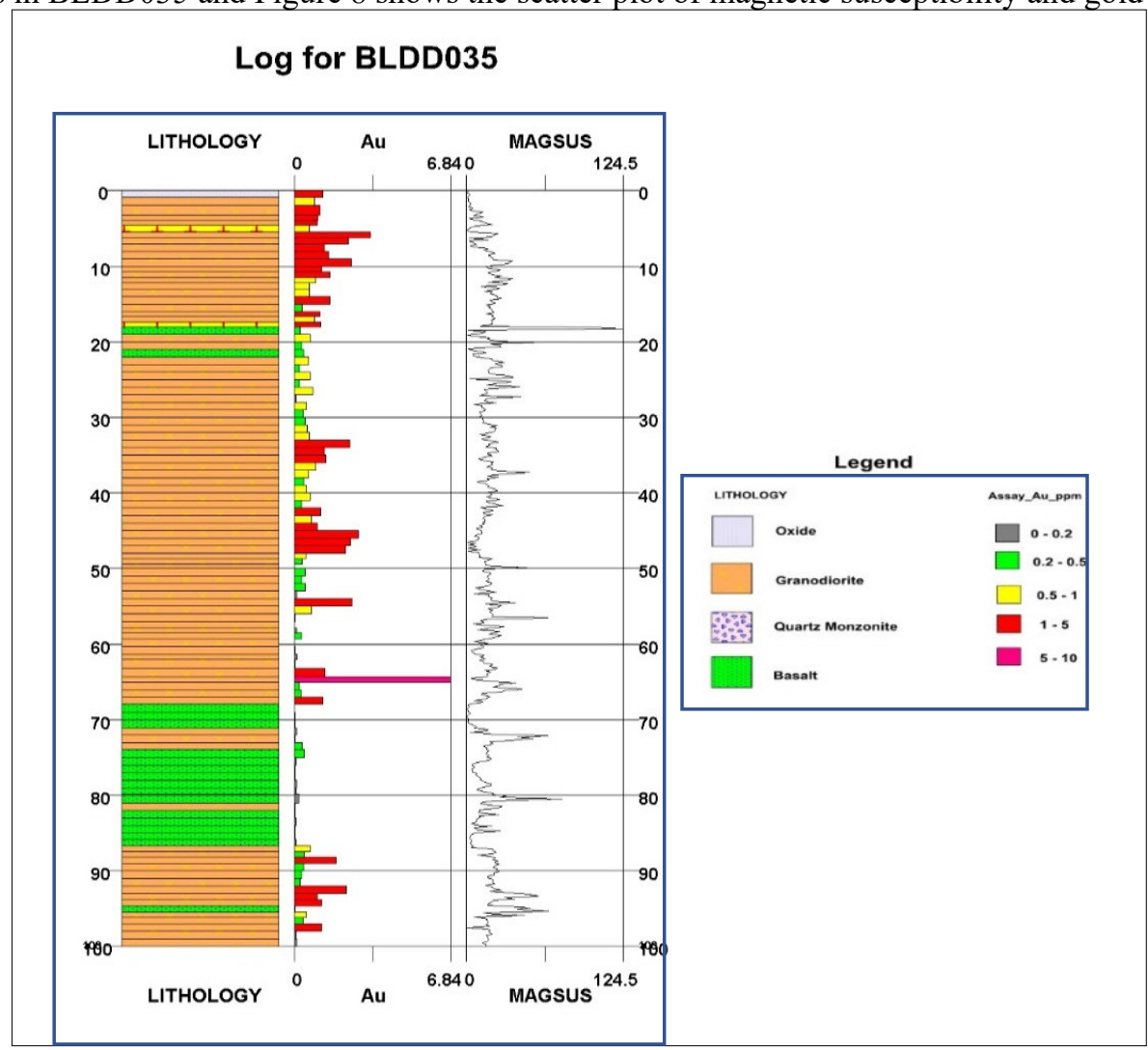

Figure 7. Basalt Showing Low Au and High Magnetic Susceptibility in BLDD035 


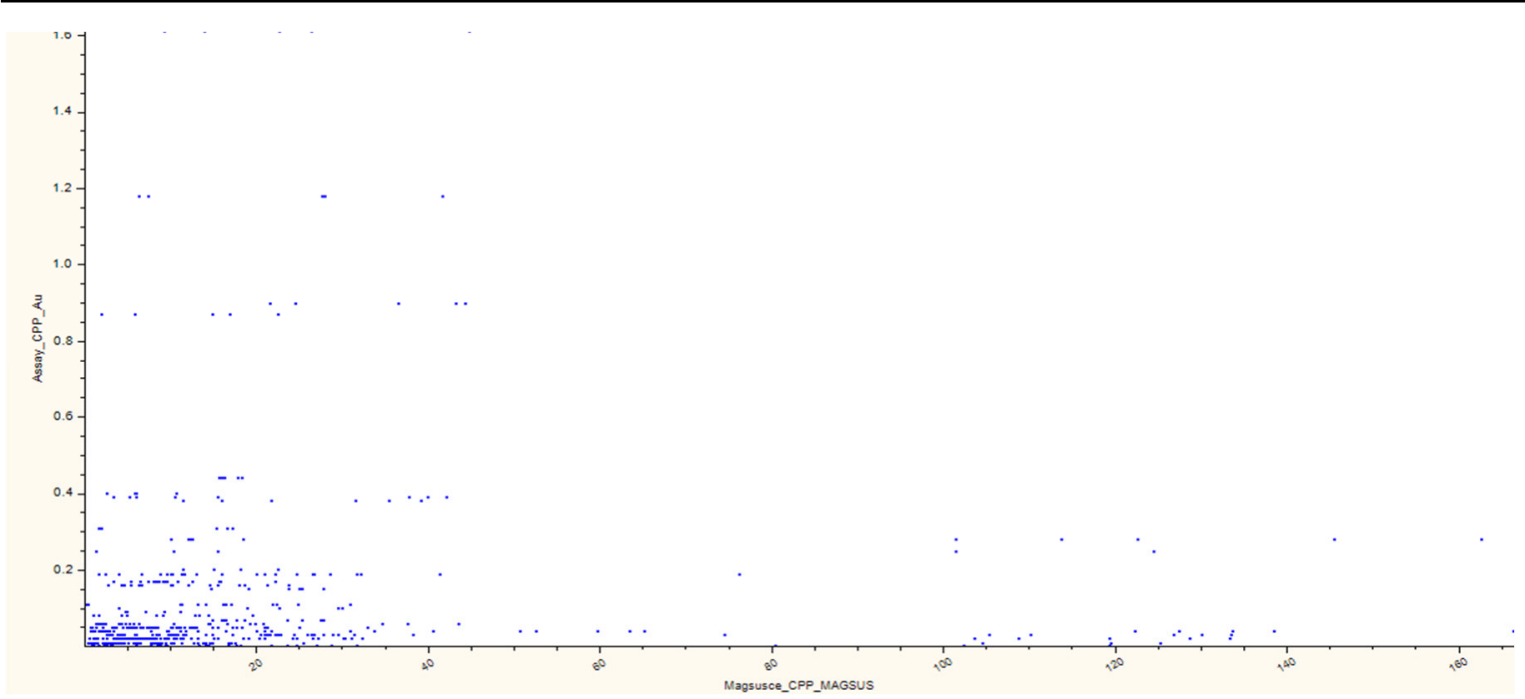

\subsubsection{Dacite}

Figure 8. Scatter Plot of Magnetic Susceptibility against Au Assay Values for Basalt

Dacite returned very low Au values. The few elevated value reported show relations to quartz veining rather than the lithological unit. An average of $10.85 \times 10^{-3}$ magnetic susceptibility value indicates a moderately high magnetic unit. Comparison of Au assay and magnetic susceptibility values show no correlation. Figure 9 show strip logs of BLDD007 showing dacite units with low magnetic susceptibility and Au values. Figure 10 show the scatter plot of magnetic susceptibility and gold values

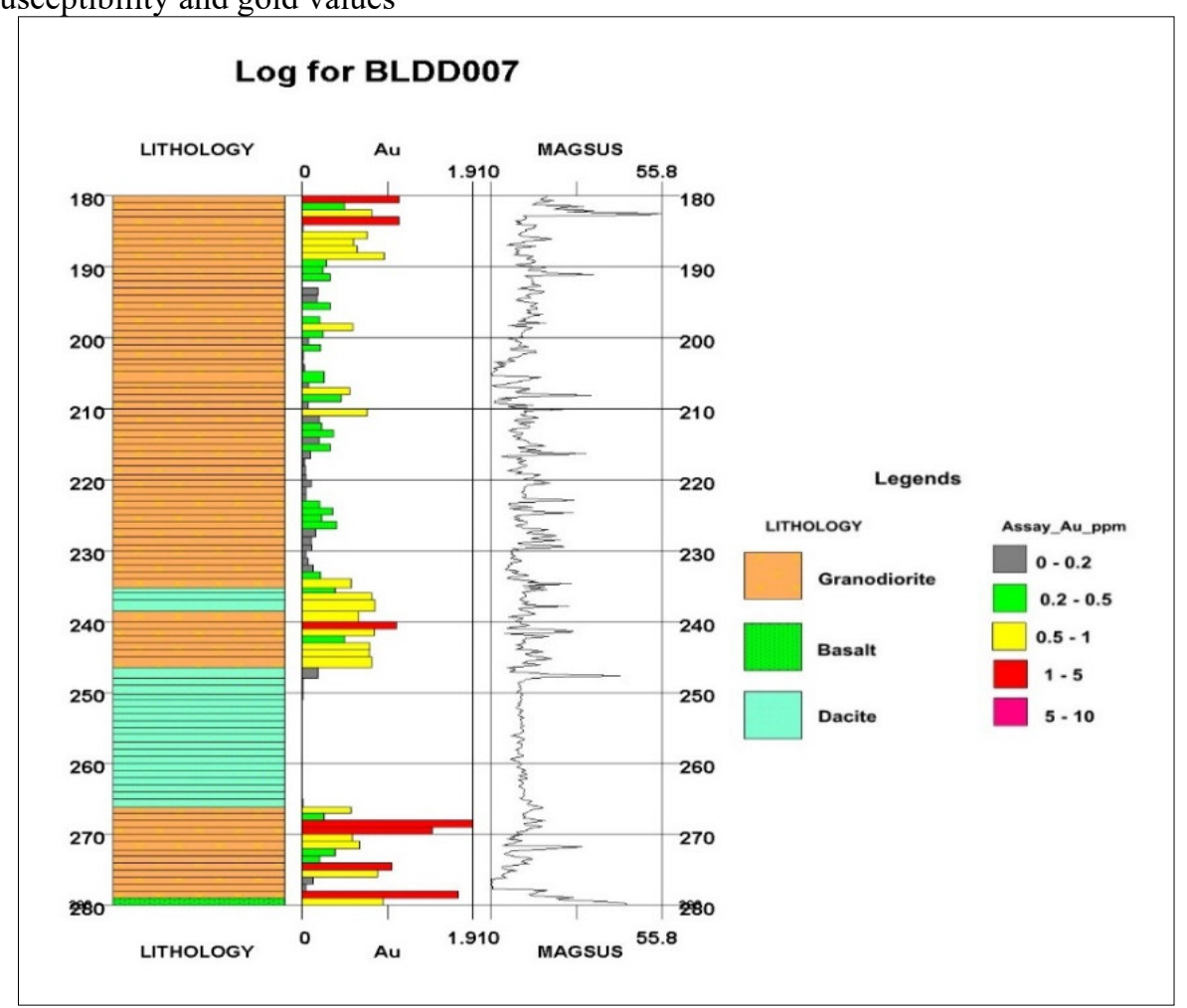

Figure 9. Showing Dacite unit with Low Au and Magnetic Susceptibility Values in BLDD007 


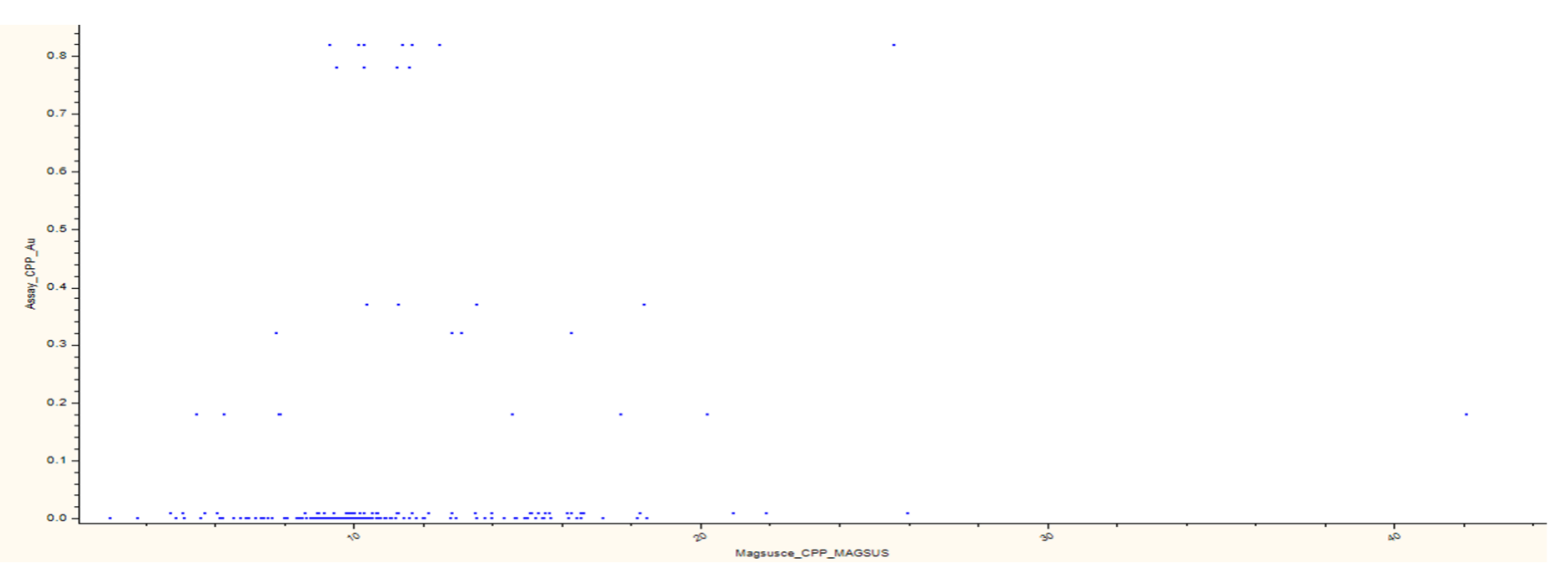

Figure 10. Scatter Plot of Magnetic Susceptibility against Au Assay Values for Quartz Monzonite

\subsubsection{Granitoids (Granite and Granodiorite)}

The granitoids host the Au mineralisation in the Balatindi mineral prospect. They are foliated, fine to medium grain, K-feldspathic units with magnetite bands concordant to foliation. Mineralisation occur in the form of chalcopyrite and pyrite, disseminated and along vein selvages. Magnetic susceptibility reading in these units is wide and varied. Comparative analysis was carried out for various ranges of magnetic susceptibility and Au assay values.

\subsubsection{Negative Magnetic Susceptibility}

Negative magnetic susceptibility values were recorded in three drill holes. The lithology reveals that these negative magnetic susceptibility zone are near surface silicified or quartz vein areas. The magnetite is weathered and leached out leaving essentially quartz. All the zones with negative susceptibility returned anomalous Au assays. However, only a few negative magnetic susceptibility values were recorded and therefore a strong correlation is difficult to establish. Figure 11 shows BLDD005 showing intervals with negative magnetic susceptibility that returned strong $\mathrm{Au}$ anomalies.

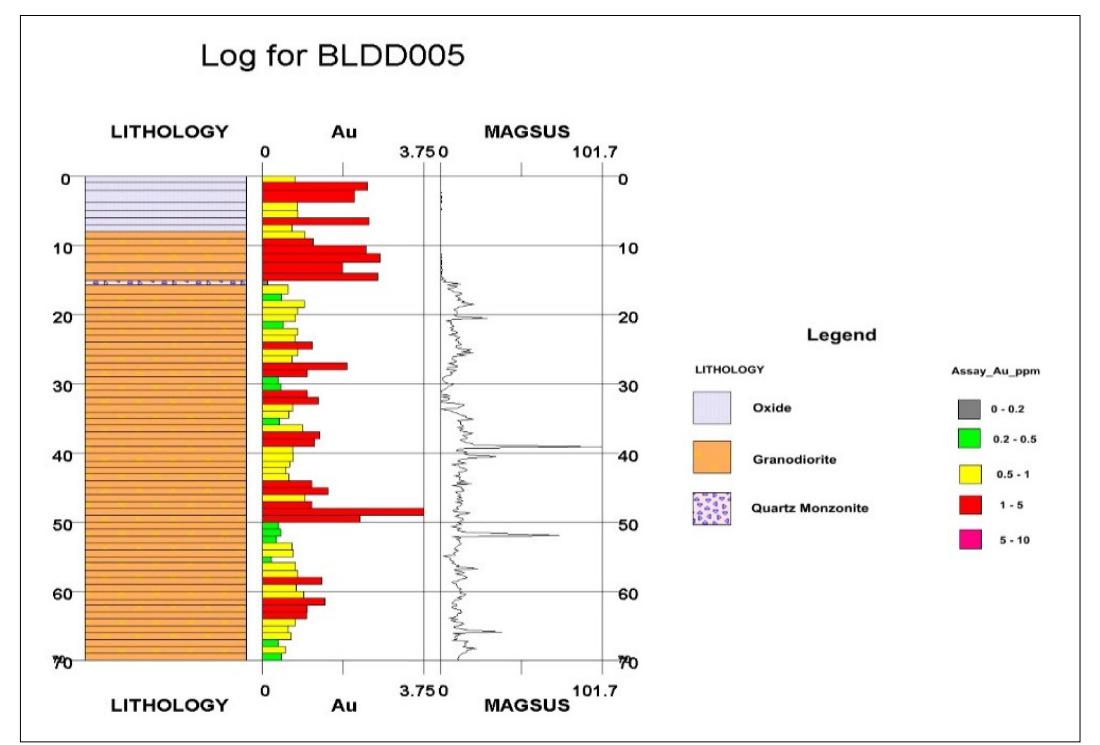

Figure 11. Negative Magnetic Susceptibility Showing High Au Values in BLDD005

\section{Low Magnetic Susceptibility}

Comparatively susceptibility values of between 0 and $5 \times 10^{-3}$ are considered low. Low magnetic susceptibility values correlate favourably with $\mathrm{Au}$ anomalies in certain intervals. This is explained by the fact that low susceptibility mark areas of silicification and quartz veining that destroys the magnetite fabric within the unit. Mineralisation within the Balatindi area is associated with silicification, quartz and sulphide (chalcopyrite and pyrite) mineralisation. Figure 12 show some intervals in BLDD004 where low magnetic susceptibility values correlate with elevated $\mathrm{Au}$ assay values. 


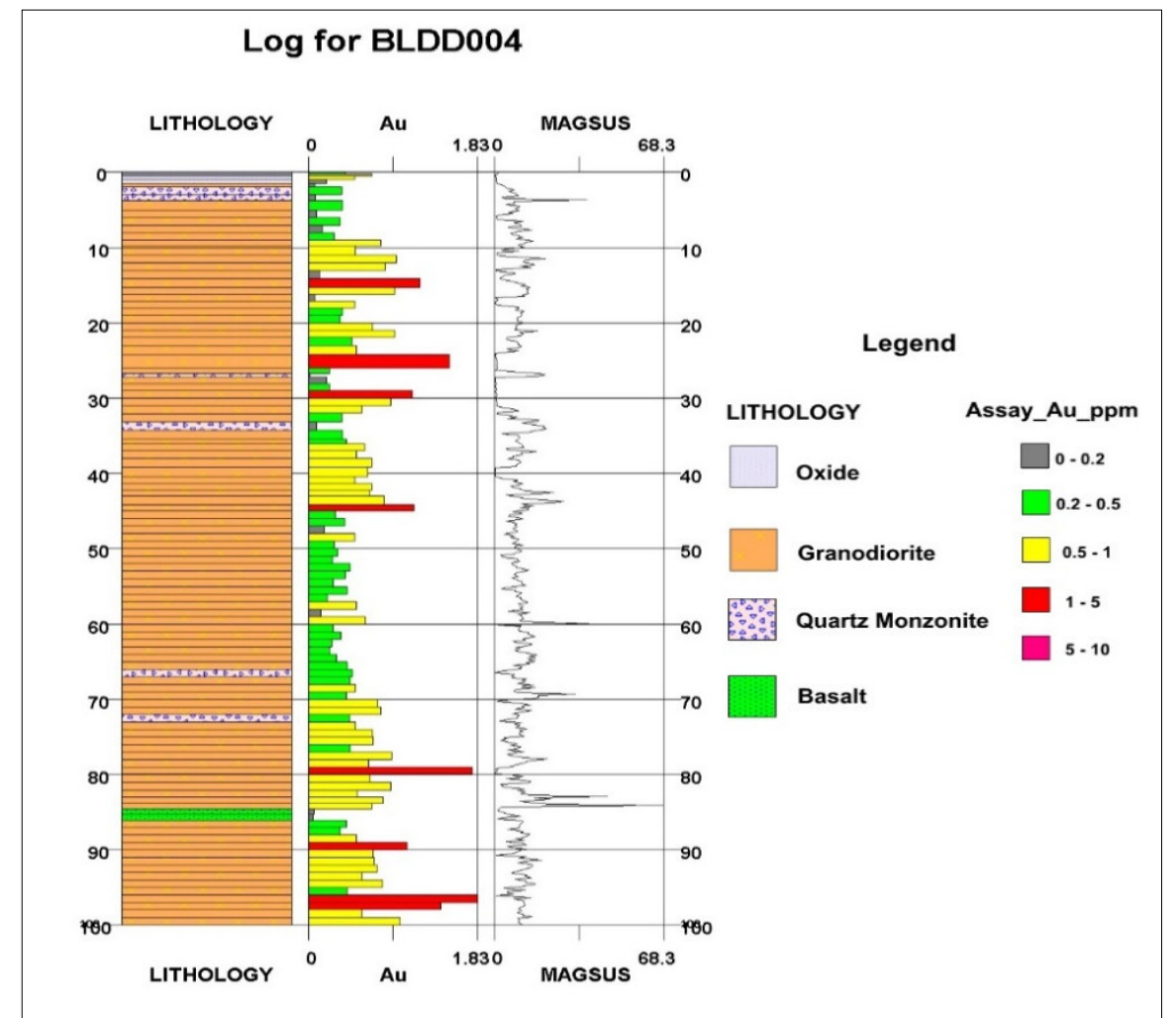

Figure 12. BLDD004 Showing Low Magnetic Susceptibility with Elevated Au Values

High Magnetic Susceptibility

High magnetic susceptibility areas exhibit an interesting phenomenon in relation to Au mineralisation. Contrary to expectation, some areas with extremely strong magnetic susceptibility also returned high $\mathrm{Au}$ anomalies. Examination of lithology reveals intense foliation characterised by magnetite banding and usually with chalcopyrite or sulphide filled joints. The relationship between the strong magnetite and the mineralisation is not well understood.

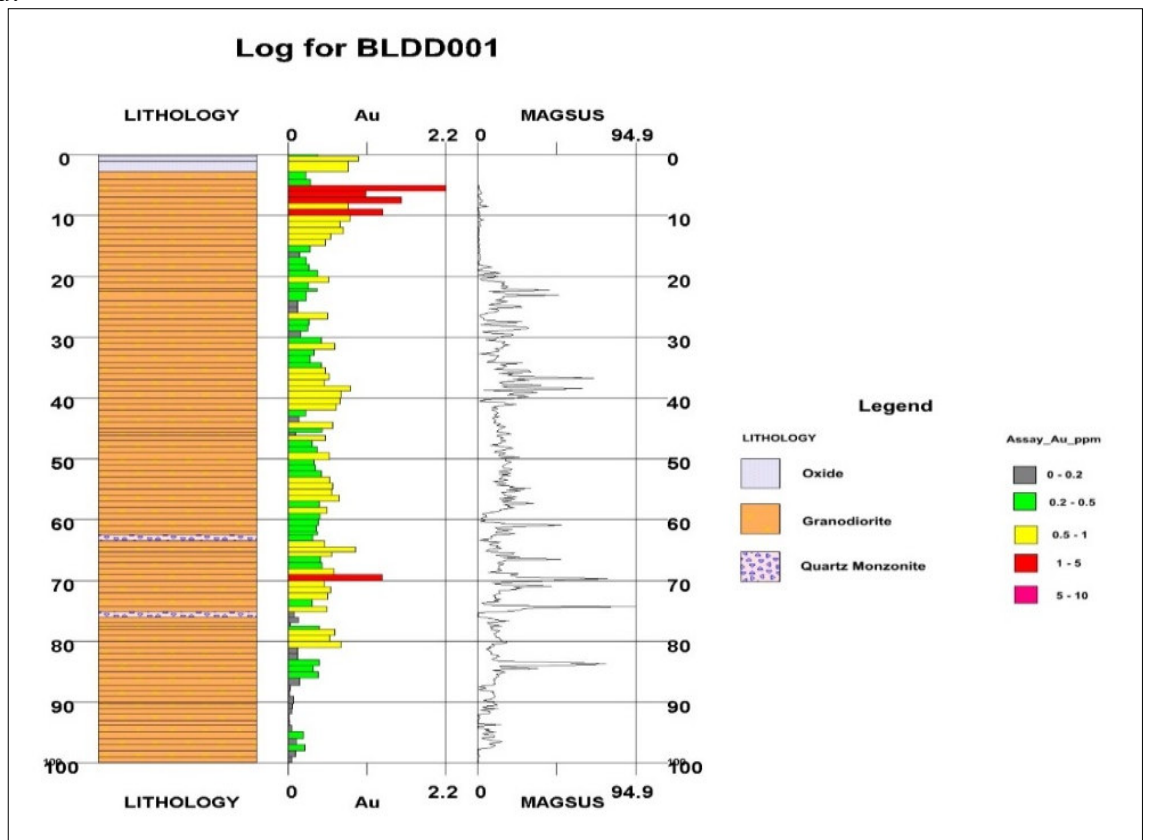

Figure 13. BLDD001 Showing High Magnetic Susceptibility with High Au Values

Statistical Comparison of Magnetic Susceptibility and Au Mineralisation

A statistical comparison of magnetic susceptibility readings and gold mineralisation was done for the CPP area. In doing this, a scatter plot of magnetic susceptibility and $\mathrm{Au}$ in ppm was drawn (Figure 14). However a meaningful correlation could not be established between the magnetic susceptibility reading and Au assay values. 


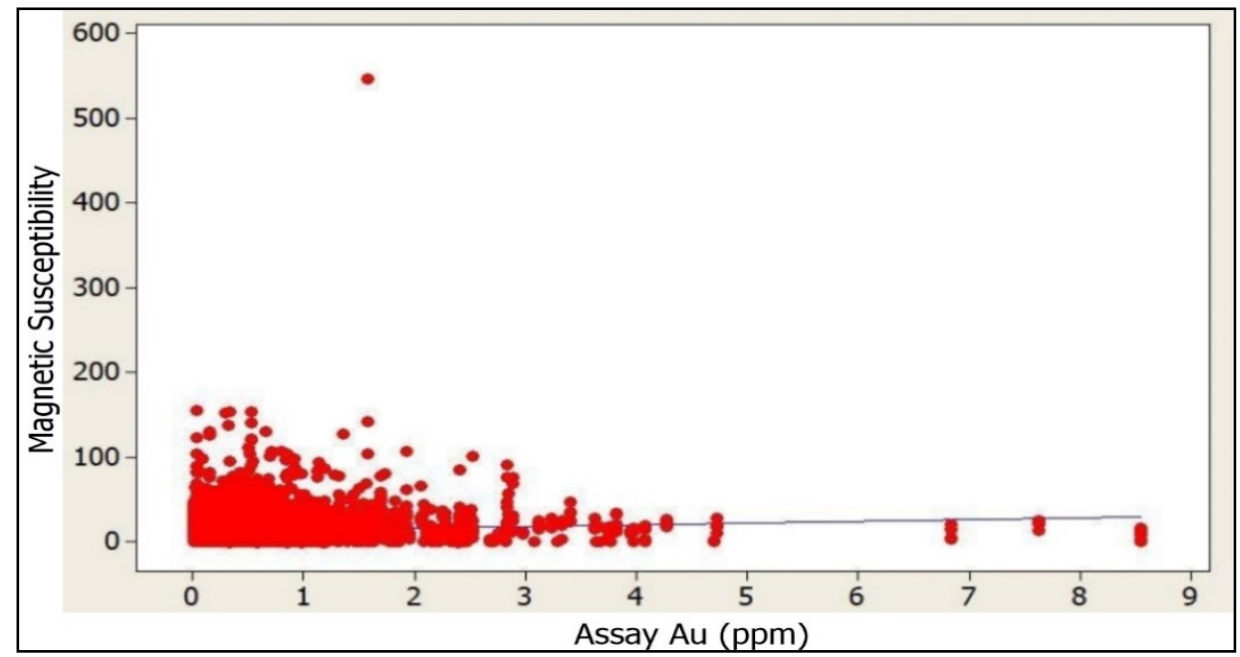

Figure 14. Scatter Plot of Magnetic Susceptibility and Au

\subsection{Radiometric Readings (cps)}

The SPP2 NF Scintillometer is a total counts instrument that records total radiations regardless of their source. Anomalous readings could therefore be from U, Th, K or a combination of the three sources. 45 and 7250 cps were the maximum and minimum values respectively recorded for the radiometric readings.

\subsubsection{Radiation cps and Lithology}

Strip logs and line plots of the radiometric cps against $U$ mineralisation and the lithology reveals that, massive rock units such as basalt, andesite and greywacke did not return anomalies for uranium. However, some fractured areas within these units showed elevated values. This is explained by the fact that uranium is highly mobile, though unable to penetrate the massive rock unit, it is able to disperse through its fractures.

\section{Uranium Anomalies}

Uranium occurs as torbernite (U-Cu phosphate), within the quartz monzonite, felsic volcanic and volcaniclastic units. Strong concentration is detected in fractured zones and along lithological contact. This is evident from the strip logs from BLDD024 as shown in Figure 16. Maximum value of 2043.7 ppm of uranium was recorded in the granitic unit. Similar anomalous values were recorded within the Felsic volcanic unit and along contact and fractured zones. This is due to the mobility of uranium in such units.

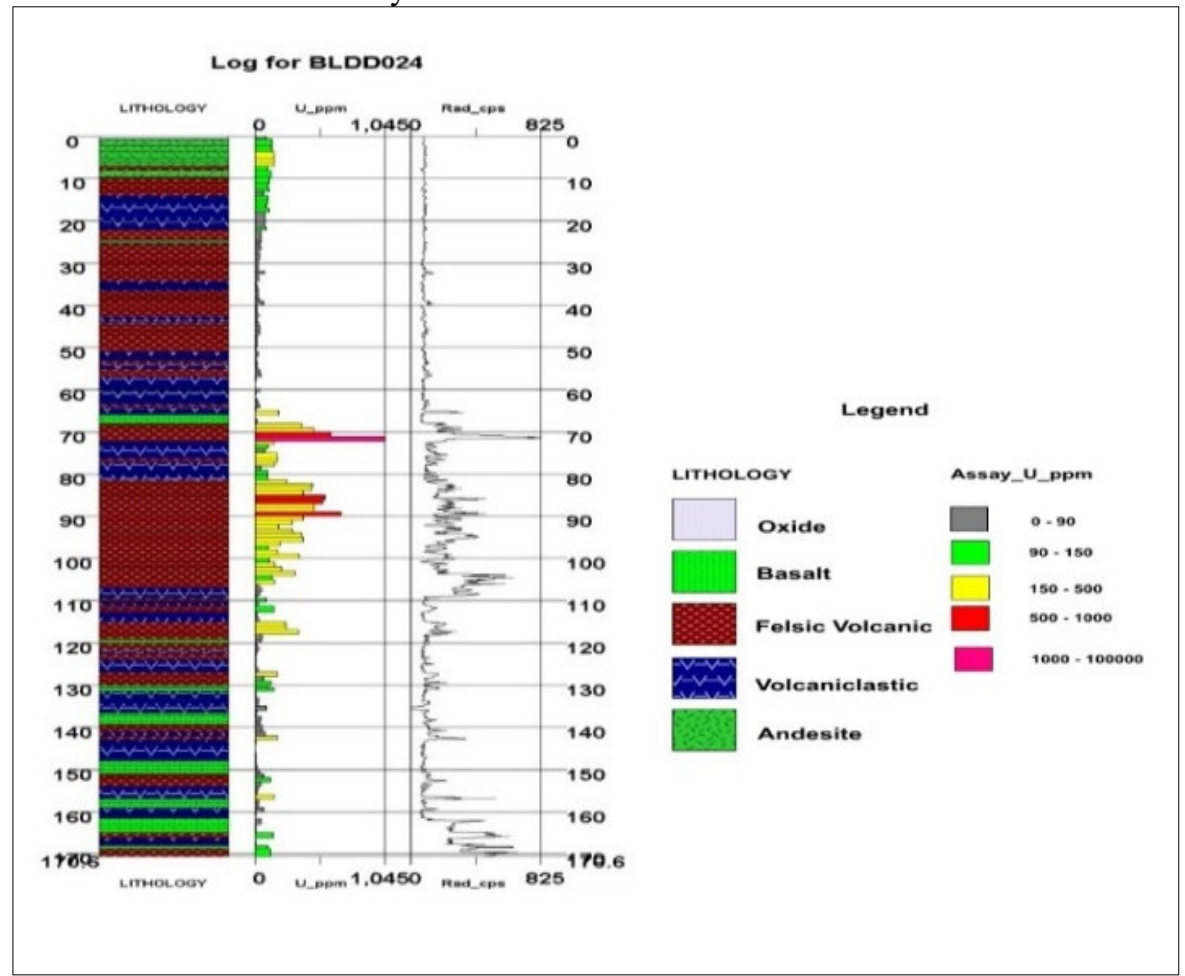

Figure 16. Strong Uranium Anomalies in BLDD024 


\section{Uranium anomalies and radiometric readings}

A strong direct correlation between uranium anomalies and the radiometric counts per second recorded by the SPP2 NF Scintillometer was observed in the strip logs for the diamond drill holes. Not only does uranium anomalous intervals give high radiometric readings, the absolute value of the anomaly in part per million (ppm) is proportional to the strength of the radiometric count per second. The correlation between the radiometric reading and the uranium anomalies indicates that the radiations picked up by the Scintillometer are from uranium sources, and not thorium or potassium sources

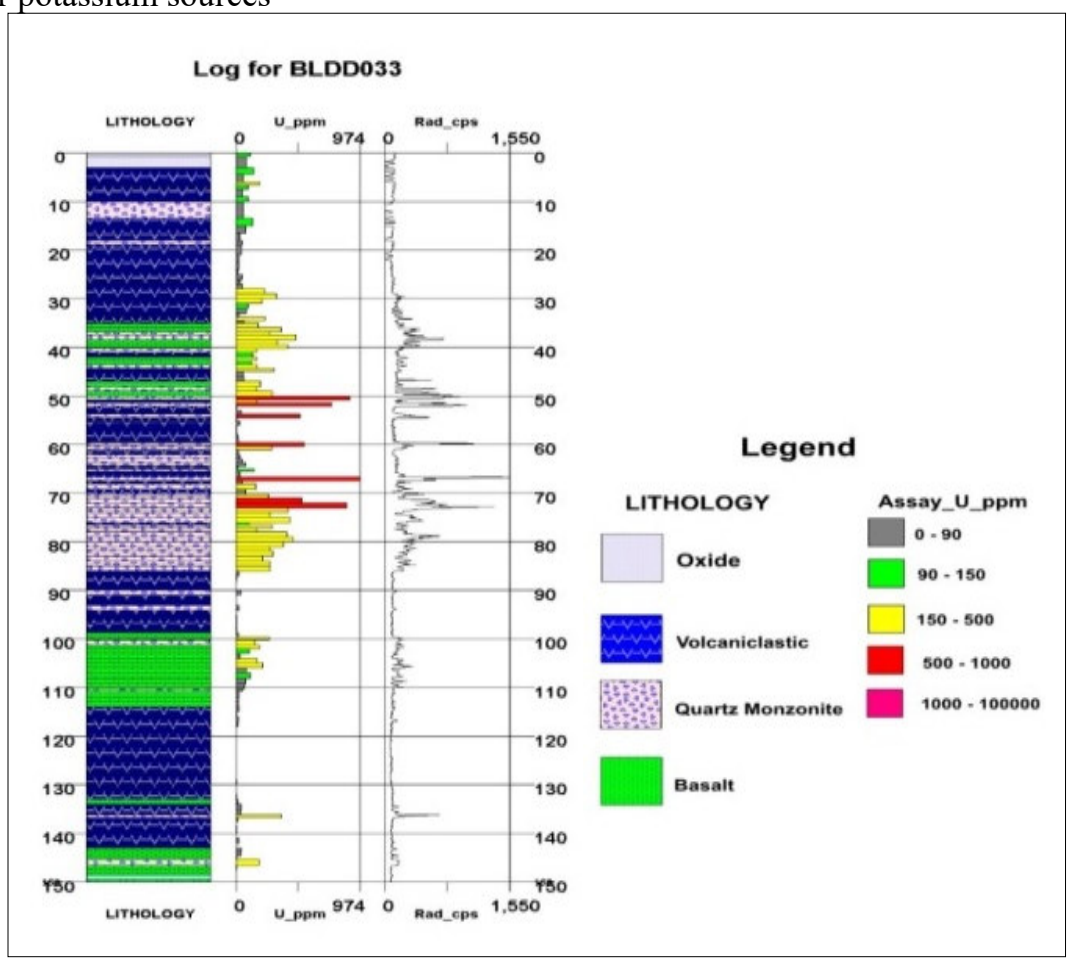

Figure 17. Holes showing Direct Correlation between Uranium Anomalies and Radiometric cps

\section{Statistical Comparison of Uranium Anomalies and Radiometric Counts per Second}

Scatter plot of radiometric cps against $U$ anomaly in ppm shows a strong linear correlation with some outliers as shown in Figure 18.

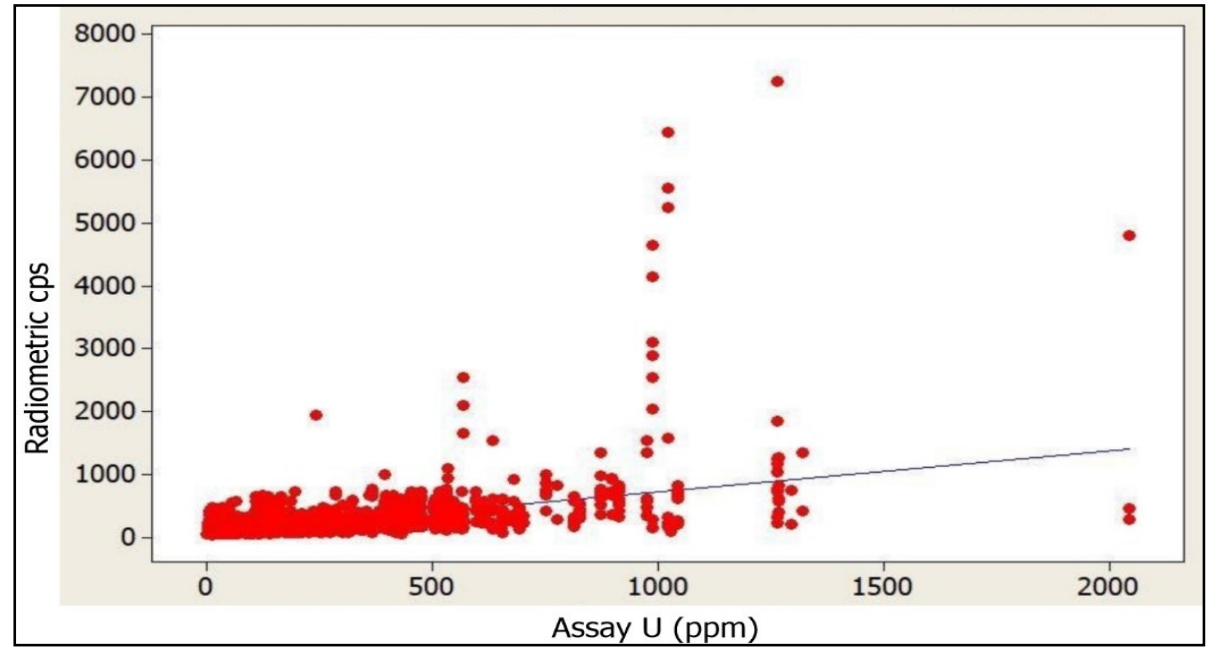

Figure 18. Scatterplot of Radiometric cps and Uranium

\section{Conclusions}

In the CPP area, drill core intervals that recorded negative magnetic susceptibility values returned anomalous gold values, but these zones were too few to base a conclusion on. Interval with low magnetic susceptibility returned both anomalous and non-anomalous values and thus no correlation could be established between magnetic susceptibility and gold mineralisation. High magnetic susceptibility intervals also showed varied assay results, elevated gold values were recorded in certain area whilst others yielded no anomalies. No correlation was therefore 
established between gold mineralisation and magnetic susceptibility in the CPP area of the Balatindi Mineral License. Magnetic susceptibility therefore, cannot be used to delineate gold anomalies within the CPP area of the Balatindi prospect.

The fact that certain intervals with very high magnetic susceptibility returned anomalous gold grades could be an indication that gold mineralisation predates the magnetite banding in the area. A strong correlation was established between the radiometric cps recorded with the SSP2 NF Scintillometer and uranium anomalies from assay results. Therefore, it is concluded that the radiometric count per second recorded is from a uranium source and thus the SPP2 NF Scintillometer can be used to delineate anomalous interval on drill core for exploration purpose. The rapid manner in which the SPP2 NF Scintillometer picks up anomalous intervals with certainty makes radiometric survey a faster and cheaper way of delineating uranium anomalies within the Area $\mathrm{E}$ part of the Balatindi property.

\section{Recommendations}

It is recommended that Heavy Mineral Concentration Analysis be carried out on the mineralised magnetite bands so to understand the relationship between the heavy magnetite and gold mineralisation. It is further recommended that paragenesis analysis be carried out between gold mineralisation and magnetite banding in the CPP area to better understand the age relationship between the magnetite banding and gold mineralisation.

\section{References}

Aboelkhair, H. and Zaaeimah, M. (2013), Potential of natural gamma-ray spectrometry for mapping and environmental monitoring of black-sand beach deposits on the Northern coast of Sinai, Egypt, Radiation Protection Dosimetry, 154(1), 81-94, https://doi.org/10.1093/rpd/ncs136.

Anon. (2009). Detailed Ground Radiometric Survey, Rcu And Hpu Properties, Roberts-Creelman And HymanPorter Townships, unpublished report, Abitibi Geophysics, 10pp.

Burey Gold Ltd, (2010). Balatindi First Quarter Report. unpublished.

Egal, E., Thie'blemont, D., Lahonde're, D., Guerrot, C., Costea, C. A., Iliescu, D. and Delor, C. (2002). Late Eburnean granitization and tectonics along the western and northwestern margin of the Archean KenemaMan domain (Guinea, West African Craton), Precambrian Research, pp 57-84.

Evans, M. and Heller, F. (2003). Environmental magnetism. Principles and Applications of Enviromagnetics, Elsevier Academic Press, 54 pp.

Gabor, P. and Peter, V. (2011). Geophysics 2, Digitalis Egyetem, Terv, 16 pp

Hrouda, F., and Kahan, Š. (1991). The magnetic fabric relationship between sedimentary and basement nappes in the High Tatra Mountain, N. Slovakia. J. Struct. Geol., pp 431-442.

Hrouda, F., Chlupacova, M., Chadima, M., (2009). The Use of Magnetic Susceptibility of Rocks in Geological Exploration, GEORADIS, pp 23-50.

Lafleur, J. (2006). The North Shore Property Turgeon, Weegee, Highway pontbriand And Ne Costebela Le Claim Blocks, NI 43-101 Technical Report,Quebec: unpublished

Lindsley, D. H., Anderson, G. E. and Balsley, J. R. (1966). Magnetic properties of rocks and minerals, in S. P. Clark, Jr. (ed.), Handbook of Physical Constants. Geol. Soc. America Mem. 97, 543-552.

Murakami, H. (2007). Variations in Chemical Composition of Clay Minerals andMagnetic Susceptibility of Hydrothermally Altered Rocks in the Hishikari Epithermal Gold Deposit SW Kyushu, Japan, Resource Geology Vol. 58, No. 1, pp1-24.

Ramadan, T. M., El Mongyb, S. A . and Salah-El-Deina, S. (2002). Exploration For Uranium And Thorium Mineralizations At Wadi Um Laseifa Area, Central Eastern Desert, Egypt: Using Remote Sensing Technique, Egyptian Journal of Remote Sensing and Space Sciences, 6 pp.

Robertson, M. and Witley, J. (2013). Balatindi Project, Independent Review of the Mineral Resource Potential and Geological Model. The MSA Group. unpublished.

Tarling, D. and Hrouda, F. (1993). The magnetic anisotropy of rocks, Chapman andHall, London, UK.

Tourlière, B., Perrin, J., Le Berre, P., and Pasquet, J. F. (2003), Use of airborne gamma-ray spectrometry for kaolin exploration, Journal of Applied Geophysics, 53(2-3), 91-102, https://doi.org/10.1016/S0926-9851(03)000405.

Tsiboah, T. and Arko, J. (1999). Magnetic Susceptibility Index Measurement and Its Implication for Gold Exploration at Ashanti Mine, Obuasi, Ghana Mining Journal, 5, 22-29.

Wemegah, D. M. (2009). Magnetic Susceptibility Characterization of Mineralized and Non-Mineralized Rocks from the Subenso Concession of Newmont Ghana Gold. Ghana Science Association Biennial Conference, p. 45.

Wilford, J. R., Bierwirth, P. N., and Craig, M. A. (1997). Application of airborne gamma-ray spectrometry in soil/regolith mapping and applied geomorphology. AGSO Journal of Australian Geology and Geophysics, $17(2), 201-216$ 